\title{
Islam and Social Integration in the Reflection of the Nusantara Society
}

DOI 10.18196/AIIJIS.2017.0071.148-167

\section{SURYO EDIYONO}

Universitas Sebelas Maret of Surakarta

ediyonosuryo@yahoo.com

\section{ABSTRACT}

Religion as a living reality of praxis system reflects the power of flexibility, appreciation and accommodation of growing traditions and cultures. Social integration is the social process of a particular member of society regardless of the cultural and religious diversity embraced, they are aware of the obligation to build solidarity based on strong relationships in building the nation. The process of social integration can work well if supported by good social norms and customs. Social norms and customs are the elements governing behavior and demanding how cultured Muslim societies behave. This research is designed using descriptive approach that aims to create a description or description systematically, factually, and accurately about the facts, properties, and relationships between the phenomena studied. The results of this study indicate that social integration in Islam is often found in people who view Islam as an understanding that can be compatible with the values of local tradition, this concept is known as Cultural Islam. Cultural Islam is a process in which external elements are accepted by local elements or vice versa. Indonesian clerics have managed to integrate Islam and keindonesiaan, so that regional traditions with restrictions that are adjusted to Islamic values.

Keywords: social integration; Islam; culture

\section{ABSTRAK}

Agama sebagai realitas hidup sistem praksis mencerminkan kekuatan fleksibilitas, penghargaan dan akomodasi tradisi dan budaya yang berkembang. Integrasi sosial adalah proses budaya keragaman budaya dan agama, dan mereka sadar akan kewajiban membangun solidaritas berdasarkan hubungan yang kuat dalam membangun bangsa. Proses integrasi sosial dapat bekerja dengan baik didukung oleh norma dan kebiasaan sosial yang baik. Norma dan kebiasaan sosial adalah perilaku pemerintahan yang berperilaku. Penelitian ini dirancang untuk menggambarkan fakta, sifat, dan hubungan antara fenomena yang diteliti. Hasil penelitian ini menunjukkan bahwa integrasi sosial 
dalam Islam sering ditemukan pada orang-orang yang memandang Islam sebagai pemahaman yang dapat sesuai dengan nilai-nilai lokal. Tradisi, konsep ini dikenal dengan Budaya Islam. Budaya Islam adalah proses di mana unsur-unsur eksternal diterima oleh unsur-unsur lokal atau sebaliknya. Ulama Indonesia telah berhasil mengintegrasikan Islam dan keindonesiaan, sehingga tradisi daerah dengan batasan yang disesuaikan dengan nilai-nilai Islam.

Kata kunci: integrasi sosial; Islam; budaya

\section{INTRODUCTION}

In general, integration can be interpreted as a condition or process of unifying the previously separate parts. This process runs through the stages that pass, is the foundation for the implementation of the next stage. ${ }^{1}$ Whether or not integration is functional, it must be peaceful and voluntary. ${ }^{2}$ Social integration is a social process of a particular member of the community regardless of the diversity of cultures and religions it embraces them to realize the obligation of building solidarity underpinned by strong relationships in building a nation. ${ }^{3}$ Durkheim ${ }^{4}$ in the study of social integration explains that social integration can be realized in the event of interdependence between specific sections. In this case solidarity is based on equality in trust and value interdependently and functionally within a heterogeneous society. This commonality in trust and value will give the collective consciousness to create unity.

Integration can occur because the visible shared values are understood from their functional aspects. Integrity in this case focuses on the function within a society. According to Durkheim, religious practice can be understood as a role for community integration and stability. Social solidarity and integration are substantive issues. ${ }^{5}$ Religion can be understood as the expression of an integrated society rather than as a source of community integration so that individuals who feel themselves one, partly because of the bond of blood, but also bound because it is a community with the same interests and traditions, then merged into collective consciousness. Durkheim connects religion and integration which actually does not mean religion produces a cohesive society but rather the phenomenon of cohesion that has a religious quality. ${ }^{6}$

In the context of Islam, religious and social integration is reflected in the concept of indigenization. Indigenization refers to the process of the occurrence of Islamic values in a community of citizens or nations, rather non-Arab nation. The term indigenization is renowned for the Cultured 
Islam. Indigenization is similar to the transformation of Islamic elements to indigenous cultural elements. If expanded again, indigenization is a continuation of the process of cultural acculturation; this is a process in which external elements are accepted by local elements or vice versa.

This paper focuses on the interrelation between religion and society as well as social interaction between various social groups that exist in Islamic discourse in the archipelago. From the study of the interrelation of religion and society, it is expected to understand the influence of religion on religious behavior of the Muslim society as has been widely applied by anthropologists to Islam Nusantara. Besides, it opens us an insight about the influence of local culture on religion, which according to Clifford Geertz's observation (1962) has succesfully, gave birth to "the Religion of Java". 7 Similarly, the study of social interaction from various social groups is expected to generate an assumption that religion has its own integrating function (social cohesion) in society.

There have been quite a lot of researches concerning the Islamic values and its influence on the Javanese culture. There is some conformity between them. Rosyada ${ }^{8}$ concluded the four elements of Islam acceptable to the culture of Java, namely (1) the value of belief in supernatural powers as a resource that can bring relief and assistance to the people, (2) beliefs about the welfare of the world and the hereafter depends on good relationships with spiritual power, (3) the response is emotional, and (4) belief in the sacred. This fact can be traced in some rural Java communities who constantly emphasize the principles of living in harmony, peaceful, balanced and based on social consensus. International researchers such as van der Kroef ${ }^{9}$ commented on the perspective on life of the Javanese as search model static, which remains obsessed with balance believing that the universe will bestow prosperity if each individual keep their mutual balance. Geertz ${ }^{10}$ observed the terms of Javanese culture selametan ${ }^{11}$ or a people's thanksgiving associated with offerings to lelembut 'unseen spirits' as the core ritual rural community.

\section{RESEARCH METHODS}

The analytical descriptive research method is a method that examines the problems in society and the prevailing procedures in society and certain situations, including about relationships, activities, attitudes, views, and processes that are taking place and the effects of a phenomenon. 
Descriptive research aims to create a description or picture systematically, factually, and accurately about the facts, properties, and relationships between the phenomena studied. ${ }^{12}$

In relation to this research topic, it will be examined secondary data relating to seeking justice through conceptualization and contextualization of Islamic concepts that synergize with the concept of society and culture of Nusantara. This is a historical approach which aimed at reconstructing the past in a systematic and objective way to find a common thread on issues that link various claims about Islam Nusantara.

\section{REQUIREMENTS FOR AN INTEGRITY}

Social integration occurs because social elements interact with each other. The process of social integration can work well if supported by good social norms and customs. Social norms and customs are the elements that govern behavior by making demands on how people should behave. If the process of social integration is not achieved then the community will experience a social disintegration. In order for a social integration to be successfully implemented, it is necessary to take into account some of the determining conditions. Karsidi ${ }^{13}$ describes some conditions for heterogeneous communities to achieve integration. According to him, integration only occurs when first, members of the community feel not harmed even the benefits will be gained greater. Secondly, there is an understanding of the norm. It means challenges and how to behave in order to achieve goals in society. Third, the prevailing norms must be consistent, to form a clear structure. Social integration takes place through three stages. First, accommodation is an attempt by different parties to argue or contradict to seek solutions or attempt to reconcile differences or contradictions or attempt to resolve differences through coordination. Second, coordination is a form of cooperation. Third, assimilation or acculturation is a different cultural contact or a better meeting of two cultures. In building the value of harmony will be found this stage or in other words there are interdependent relationships so that each party aware of its role. In this process there is no in-group (us) and out-group (them), both have the same role in building a better life.

According to William F. Ogburn da Mayer Nimkoff' ${ }^{14}$, the terms and condition of a successful social integration must meet certain criteria as follows; 
a. Community members feel that they are successful in filling each other's needs with one another. This means the physical needs of clothing and food and social needs can be filled by the culture. Fulfillment of these needs causes the community to keep each other's attachment to one another.

b. Communities succeeded in creating consensus on the social norms and values that are preserved and made guidelines in interacting with each other, including agreeing on things that are in accordance with their culture.

c. Norms and social values that apply long enough and run consistently and do not change so it can be a standard rule in the process of social interaction.

\section{THE DIALECTICS OF RELIGION AND CULTURE}

To open up a discussion on the religious perspectives on multiculturalism, I began by asking a fundamental question. Is there a religion that does not use culture as a means of the spread? Is there any religion that comes from God in the form of a set of ready-made living systems for all time and place?. Is there a pure religion (Islam) that does not use the symbolic or cultural order that human society possesses, when it is accepted and developed in different parts of the world (Arab and non-Arab) ?. Then is there anyone who born into a religion?.

These questions are important to reflect on, since every religion, unconditionally Islam is present for human beings. And when man is present, he/she walks through the realities of his life constantly confronted with and by the growing tradition around him/her. It is tradition that gives meaning, color, norms and customs so that people can survive in a community with their own ethics and aesthetics. Thus, the answers to the above questions seem to be negative. This means that objectively speaking there should be no religion that does not use symbolic and cultural tools when present in the midst of human life. Religion is also not a readymade operational guard in all times and times. Conversely, religion is something that continues to be interpreted and developed.

In the context of Indonesia, Islam is nothing but a religion that also contains a tradition of believers of its people who have existed and developed long before Islam was present. Of course it must be known that the Islamic tradition and civilization that has been developing in Islam is not 
merely the result of plagiarism, but also the creation of Muslims themselves when interpreting the Qur'an and As-Sunnah on one hand, and reading the traditions that has grown on the other side. The problem then, how Islam views tradition? Even though, commonly the definition of tradition is still in the intellectual debate for years and years. However, tradition can simply be interpreted as a translation of the human customs, beliefs, and teachings from generation to generation. Thus, the history of the past continues to occupy an important position in a tradition. Tradition therefore relates not only to the basis of legitimacy, but also to the system of authority.

\section{CULTURED ISLAM AND REFLECTION OF THE SOCIAL INTEGRA- TION}

In the true ideals of true Islam, the coveted Muslim community is not a society in which only Muslims are granted their rights and are regarded as citizens, but all individuals are also entitled to their rights within the legal framework. 'Protecting those rights' is among the basic tasks of the state. Such societies do not want to dominate others and do not want to be dominated. The cultivated civil society based on the 'collective identity' whose attainment demands a sustained effort by scholars and thinkers. This dream cannot be realized overnight, but throughout life itself. Therefore, the dream manifestations are slow, dependent on an honest understanding, a retest of the heritage of Islamic civilization and its intellectual and doctrinal traditions, and a thorough, scientific and philosophical understanding of the modern world on the other. On the shoulders of the learned thinker and man the task is carried, and ultimately that success depends on the politics that serve the thought and the virtue, and does not act in the way of their work. ${ }^{15}$

The sociological discipline provides insight into how a society builds negotiations and interdependence between religion and society is an important goal of the functioning of religion in society. Joacheim Wach, shows the mutual influence between the two factors; First the influence of religion on society and the second, the influence of society on religion. ${ }^{16}$ The Religion of Java in the view of Clifford Geertz is the sociological impact of the interdependence relationship.

Given the history of Islamic origins in the Island of Java, all religions in Java are imported. Hinduism comes from India, Buddhism from India- 
China, Islam and Christianity comes from the Middle East (Arab). ${ }^{17}$ The original religion of Java was the "religion" of the animism. It is a belief in spirits and rulers outside of itself. This historical fact reinforces that religion in Java is a hybrid product of the cross-cultural culture of religions that once came there. The Islamists call it a syncretic religion. Walisongo realizes this as a reality so their da'wah or preaching method which renown for its tolerant and appreciatethe local traditions. The preaching of Walisongo in Java has used the local wisdom and tradition as a method. Walisongo did not completely erase local traditions and replace them with Islam. Walisongo maintained the aspects of tradition and tried to adapt it to the teachings of Islam without undermining its substantial value, one of the aspects is i.e. the ancient mosque building still maintains the HinduBuddhist model on its three-tiered dome aspect.

Internally, Islam and Javanese culture often become the reference of the discourse of Muslim life in the archipelago. Over the centuries ago when Islam came to the archipelago, the two dialogue with other beliefs such as Hinduism, Buddhism and other local religions. Javanese culture, on the other hand, is a legacy of Javanese society for thousands of years and continues to enrich the world's cultural treasures. The relationship between Islam and Java, therefore, attracted the attention of researchers and has produced many scientific papers. Indonesian clerics have managed to integrate Islam and the Indonesianism, so that for this area has been considered in accordance with Islamic values, because Islam concerns the values and norms, not the taste or ideology let alone the custom. In other words, if the value of Islam is considered in accordance with local custom, it is not necessary to change according to Arabian tastes, traditions, customs or ideologies, because if it is done it will cause cultural shock, while filling Islamic values into the existing cultural structure is much more effective rather than replacing the culture itself. ${ }^{18}$

Clifford Geertz ${ }^{19}$ created an analytical framework by classifying the Javanese-Islamic society into three variants, namely; Abangan, santri, and priyayi. For Geertz it rests on the assumption that the Javanese worldview is a Javanese religion confronted with a social stratification system in Java. This means that the three variants of Javanese society are influenced by three core social structures (village, market and government bureaucracy). In its pronunciation, three different environments (rural, market and government offices) coupled with different cultural historical backgrounds 
(related to the introduction of Hinduism and Hindu and Islamic civilization in Java) have manifested the existence; Abangan (emphasizing the animistic aspects), Santri (emphasizing the aspects of Islam) and Priyayi (emphasizing the aspects of Hindu). ${ }^{20}$

In venturing that view, Geertz ${ }^{21}$ emphasizes that Islam in Java is a collection of expressions of faith, doctrine, ritual and others practiced in accordance with local traditions or places and times along with their development and spread. The phenomenon of Islamic integration with the social environment of Javanese society as reported by anthropologists such as Geertz is a manifestation of the indigenization of Islam. This phenomenon explains that in the teachings of Islam is contained a dynamic religious understanding and rests on the historical journey that has been going on. Consequently, the reading results obtained from these religious conscious interactions result in a different style, model or religious attitudes. In this case religion can function as a basis for a process of humanitarian awareness critical of forms of injustice, marginalization, discrimination and oppression, even in the name of religion though.

\section{BETWEEN FLEXIBILITY AND SOCIAL INTEGRATION IN CUL- TURED ISLAM}

In a plural society, religion can be a unifying factor, as it can easily be misused as a divisive tool. Religion on the one hand creates a common bond between both community members and in social obligations that help unite them..$^{22}$ Religion as a praxis system of living reality has the power of flexibility, appreciation and accommodation of traditions and cultures that develop from generation to generation without anyone daring to question its validity and authenticity. This belief accepted and practiced as a necessity taken for granted that no one dared to oppose it. Various forms of ritual selametan (harvest, clean village, spirits worship, cemetery and circumcision) are always not considered valid if each of them to be violated/having different views from what have been inherited and taught by the ancestors.

Indigenous and obedient Muslims in traditional mythology practice cannot be equated. It is not uncommon in certain traditional Muslim societies to view such magical things as sacred places, magical performances through barongs and other ritual practices as a core part of religious practice, despite its existence outside the domain of dogma and religious teach- 
ings. Such cultural terrain is seen as mere custom, although they also recognize that their involvement with the rituals will further legitimize the truth and altitude for the place's observations.

Some cases in indigenous Islam that hold the tradition of selametan, with its various attributes, forms, dimensions and meanings, are always oriented towards cosmic continuity and harmonization. Selametan is a common phenomenon that internalizes the Javanese life system, however it can be judged to be a social harmonization effort especially from Islam and local traditions often packed in multivocality ritual symbols that never produce agreement, full of ambiguity but also full of order. The problem that arises is whether cultural Islam can be regarded as valid in the perspective of Islamic doctrine. This legitimation is important in the socialization and internalization of Cultural Islam as the discourse of the liberation of the ummah among Muslims itself (read; radical Islam).

With the embedding of local values of tradition in Islamic practices is in order to form an Islam that is accommodative to local culture. Indigenous Islam is not an attempt to avoid the emergence of resistance from the strengths of local cultures, but aims to strengthen the local culture not to disappear. ${ }^{23}$ Thus, the core of indigenization is a need to avoid the sharp distinction between culture and religion or more specifically between Indonesian culture and Islamic teachings.

\section{SELAMATEN AS AN ACTUALISATION OF THE SOCIAL INTEG- RITY}

Selametan in its extending definition concern with serving foods for offerings recited verses of the holy Qur'an. The offering as the accompaniment of slametan ritual is mainly served to gain the blessing from Prophet Muhammad. Geertz ${ }^{24}$ studied selametan which covers descriptions of (1) the core ritual in the Javanese culture, (2) a ceremony inspired by understanding of animism which aims to promote solidarity among the society, and (3) the main thing in rural ritual. Geertz's understanding on this ritual appears to be contradictory to the term selametan understood by most Muslim of Java. The criteria provided by Greertz received criticism from Woodward. ${ }^{25}$ The results of this field study on the Javanese culture summarized in Woodward's findings ${ }^{26}$ generate five claims (1) selametan essentially is a parable complex ritual which links barokah (blessing) ranging from the belief brought from Arab culture and adapted by society in South- 
east Asia, (2) selametan is not only a ritual of the villagers, (3) the purpose of religious and social selametan found in the teachings of mystical Islam (Sufism),(4) not all elements practiced in selametan beyond the teachings of Islam, it is, indeed, the essence of the teachings based on Quran and Hadith, (5) there is a belief which claims selametan linked with the preIslamic teachings underwent a process of cultural acculturation, therefore, some cultural and religious terms brought into and acceptable to the Islamic teaching.

The word selamet, according to Geertz has a complete meaning and has been long deemed to contain the Javanese paramount values. The word selamet embodies the concept of prosperous, safe, prosperous, and protected from disturbances of natural and supernatural dangers. ${ }^{27}$ In the Javanese view, the word selamet represents the whole human ideal in relation to God and the universe. From this word selamet Javanese rituals appear in the form, for example, tingkeban (rituals pregnant of seven months first child), Babaran, Pasaran, Pitonan, and others. Also the salvation ceremonies for the dead, marriage, harvest, and others are basically meant to seek safety or selamet.

The Javanese and Islamic worldviews at the sociological stage converge into cultural forms. Wali Songo adopted wayang, art, and gamelan in spreading Islam. At that time, this method became the underlying philosophical method. Secondly, socio-fact is the social system and human activities carried out in life, and the artifact, which is the form of objects or buildings that are the result of the previous two stages. From the point of this anthropological theory, the mosque's buildings by borrowing the structures of Islam are not unconscious, but are based on careful considerations. And this confirms the occurrence of the indigenization of Islam in the form of artifacts. Even when examined more deeply, the dome of three is actually the adoption of the Hindu tradition. The triangular dome in Java is almost similar to that of a mosque in Kerala, South India. And the three-story building is a Hindu tradition as found in the temple building both in India and in the archipelago.

In Java the development of Islam has been interrupted by the death sentence case of Sheikh Siti Jenar by orthodoxy defenders. It is also experienced by abangans who are criticized by orthodox Muslims for practicing Islamic syncretism. The peak of conflict between santri and abangan occurred in the tragedy of G 30 S in 1965 in which the killing of abangans 
by santri affiliated with Islamic organizations was conducted in a number of areas in Java. ${ }^{28}$ In the context of the history of Islamic civilization, there are also examples of how radical sects such as khawarij, for example, could not develop in history and died at a very short age. This is an important lesson that has become evident. The scholars of the past, apparently, have studied this iron law so they do not impose Islamic teachings with a legal-formal approach.

The doctrine which emphasizes the position of selametan or any religious and ritual practice with the martial arts has been practiced and passed down through thousands of years (emphasized in a case study of PSHT martial arts school by Ediyono. ${ }^{29}$ By undergoing a ritual, martial arts practitioners may transcend physical combat to the philosophical quest for meaning. In addition, the ritual practice does not take away the combative physical element of the arts; it just establishes a connection between the individual and his universe.

\section{EFFORTS TO PHILOSOPHICALLY DEFINE THE PHENOMENON OF THE RELIGION OF JAVA}

For the Javanese, the whole life is a manifestation of the absolute contingent. It is impossible to separate the sacred or holy with the mortal. Indeed, morality does not necessarily come from religion, nor did the Javanese epistemology always derive from ethics. Javanese philosophy views experience of personal life as a religious experience. ${ }^{30}$ While the existence of morals or manners contribute to shaping the nature of Javanese life which tries to harmonize between the microcosm and macrocosm life, vertical and horizontal relationships. In addition to maintaining good relationship with among the communities, the people concern relationship with the creature through being a devout servant of God. Javanese thinking embodies a view that people can find peace through interaction with social (including the surrounding nature) to know more about the entities in themselves as divided into inward and outward parts.

Efforts to culturally define the phenomenon of Javanese epistemology can be explored by restoring this phenomenon to the area of social science studies. Revealing the logic and belief system of the Javanese people in their socio-cultural realm, it bears our minds on the philosophy of symbolic meanings practiced by local people as well as the beliefs on mystical beings. Concerning this attitude, Malinowski ${ }^{31}$ views on the embody be- 
lief systems and logic based on the ethnographic studies of Southeast Asian communities which include socio-cultural aspects of the population. In this case, the identity embedded in the Javanese society practically concerned with the magical beliefs.

....the foundations of magical belief and practice are not taken from the air, but are due to a number of experiences actually lived through, in which man receives the revelation of his power to attain the desired end. ${ }^{32}$

The epistemology of Java embodied in a term called ngelmu 'science' which refers to a form of mystical or spiritual, nor that it is intellectual but more likely intuitive intelligence. To discover how ngelmu obtained, one must be able to seep into his deepest heart, he or she should undergo three-dimensional processes; ranging from the coarsest part of her body, smooth and then to the most subtle, sublime and glorious. ${ }^{33}$ Additionally the Javanese knowledge is conceptually perceivable through performing ritual. By the symbolic ritual it was perceived as a means to seek for the truth. To confirm Ricoeur's view ${ }^{34}$ on symbol, 'different symbols are rooted in the human experience'.

Based on the acculturation of Javanese culture, Islamic teaching inspired the principle of Javanese mystical journey which summarized in four levels. The Javanese spiritual journey described by Hadiwijono ${ }^{35}$ departs from the outward condition, starting from the most rugged parts of the body towards the most delicate things, this belief accordingly has been much influenced by mystical Islam (Sufism). In Islam, the lowest level in acquiring knowledge is the shari'a of life guided by religious law. The second is the tarekat 'congregation' that is the degree to which a person is aware at the time of undergoing the deepest meaning of life by performing rituals and obeying the religious law. The third level is hakekat 'essential', it is a growing level of awareness and understanding which can only be done as individual perceiving their role life entirely to serve the Creator. The last level called makrifat which is the degree that the individual and his soul merges with the soul of the universe, despite of remaining the nature of human needs (eating, drinking, sleeping, etc.), at this level one regards himself as the representative of God on earth. The fundamental aspect of Islamic mystical teachings which most phenomenal and adopted by the Javanese culture is on a concept of manunggaling kawula Gusti inspired by the Islamic understanding of wahdatul wujuda 
claim of human beings can be united with his Lord. This is the highest level of knowledge in Islamic mysticism. ${ }^{36}$

\section{THE RELIGION OF ISLAM AND SOCIAL INTEGRATION}

When Islam has experienced indigenization, its existence is no longer cultivated in the hegemony of a single commentary such as the Arabocentric interpretation characteristic of Arab culture. The meaning of a scripture is often influenced by its interpreters and the interpreters are influenced by their environment and cultural inclinations. The indigenized Islam is, therefore, highly relevant to the particular Javanese cultural contexts and the culture of the archipelago in general.

In principle, the indigenization of Islam and the great ideas of the world into the Javanese locality is a natural process that can not be stopped. This kind of process also occurs in other regions. As Islam spread and went out from the mainstream of Arabia, Islam acculturated with "occupation" territories. Africa, India, South Asia, Europe, America, Southeast Asia and Australia are regions that have their own civilization when Islam comes. That is, the interaction between intellectuals between Islam and local cultures gave birth to a more insightful Islamic treasury. ${ }^{37}$

This historical fact forms the basis for the theory that the indigenization of Islam in Java is, in essence, a continuation of the above historical process. This indigenization process takes place subtly and takes place in a time-lapse. This indigenization takes place at the community level as well as at the central level of the center of the Javanese Palace ${ }^{38}$. At the community level, the indigenization proceeds more slowly. While at the royal level goes faster. It should be remembered that social changes are mobilized by the elite. Therefore, the palace where the king and his ruling structure can determine a set of rules. Islam in the palace actually interprets Islam within the framework.

Maha Patih Gadjah Mada (1364 AD) has actually come into contact with Islam spread through merchants in ports. Just as a newcomer religion, Islam has yet to show off. Islam coexists with Hinduism, Buddhism, and Javanese origin. In its contexts, of course, Islam does not directly openly teach the main points of doctrine. There are compromises between Islam and culture. The new converts are those who were Hindus, Buddhists and Animists ${ }^{39}$. The converts, of course, are not entirely abandoning their old traditions. Adaptation, acculturation, and enculturation 
continue to occur and shaping what Islam today is largely practiced in Java 1920.

Thus, when Islam was slowly getting stronger and establish an Islamic government in Demak (1478-1549) and then it grabbed Majapahit in 1478 AD, Muslims have moved into a religious state. Raden Patah whose later became the king of Demak is the son of one of the descendants of the Majapahit who married princess of Champa. In fact, according to Slamet Mulyana, the last kingdom of Majapahit already embraced Islam Before it finally collapsed. ${ }^{40}$

The indigenization of Islam is the stage of Javanese understanding of Islam. The kings of Mataram Islam since then no longer ask for legitimacy on the Hindu-Buddhist breed, still directly to the Caliph in Mecca. Islamic symbols began to be made to enlarge the legitimacy of the kings in addition to Javanese symbols. In the case of the Babad Tanah Jawa, for example, the Mataram kings were linked as compromising, supple, and more substantial in substance instead of the form. ${ }^{41}$ Thus, scholars as agents of change and / or cultural intermediaries play a precise role in marrying local traditions with Islamic traditions. This is different from the more formal and illegal figh (Islamic Jurisprudence) dimension so there are some clashes, although this is more "hidden" in nature.

Indeed there was an occurring conflict between the Islamic jurisprudence (figh) and Javanese traditions. But for the Javanese, harmony or harmony between jagad gedhe 'the big universe' (macrocosm) and jagad cilik 'the small universe' (microcosm) is so prominent that it is strived to be well guarded. This effort finds its form in the term selamet. The Javanese have a very good concept of "rasa" 'spiritual taste' in the face of collisions $^{42}$. And it seems that in the context of Islamic indigenization has been a very successful form of religion.

The indigenization of Islam will continue in community dialectic with the acceleration of change both qualitatively and quantitatively. This means the involvement of the intellectual elite who plays the cultural brokers so that the Islamic indigenization goes without a meaningful dispute. With a critical attitude of openness, Muslim intellectual elites will respond appropriately and provide key concepts of how Islamic relations and Javanese culture are laid in order to generate synergies. 


\section{CONCLUSION}

Religion as a living reality of praxis system reflects the power of flexibility, appreciation and accommodation of growing traditions and cultures. Social integration is the social process of a particular member of society regardless of the cultural and religious diversity embraced, they are aware of the obligation to build solidarity based on strong relationships in building the nation. The process of social integration can work well if supported by good social norms and customs. Social norms and customs are the elements governing behavior and demanding how cultured Muslim societies behave. Social integration in Islam is often found in people who view Islam as a concept that can be compatible with the values of local tradition; this concept is known as Cultural Islam. Cultural Islam is a process in which external elements are accepted by local elements or vice versa. Indonesian clerics have managed to integrate Islam and the Indonesianese, so that regional traditions with restrictions will be thn adjusted to the Islamic values.

\section{ENDNOTES}

1 Mas'oed, Politik dan Pemerintahan di Asia Tenggara. PS Ilmu Sosial dan Ilmu Politik, (1991), h. 2

2 Karl W, deutsch, et al., Political Community and the North Atlantic Area. Social Research (24), 4 (Winter 1957), h. 486-488

3 Dalhat, Islam and the Problem of Social Integration in the West. (3) 7. ISSN: 2411 5681. Accesed from:www.ijern.com, (2015) h. 274

4 Johnson, Teori Sosiologi Klasik dan Modern, (Jakarta, Gramedia, 1988), h. 181188

5 Ibid. h. 166

6 Robert N. Bellah, and Hammond PhillipE, Varieties of Civil Religion,(New York: Harper \& Row,1980)

7 Harry J. Benda., Review: The Religion of Java. by Clifford Geertz, The Journal of Asian Studies. Association for Asian Studies. Vol. 21, No. 3 (May, 1962), h. 403-406. DOI: $10.2307 / 2050716$

8 Rosyada Dede, Materi Pokok Agama Islam [Trans.The Subjects of Islamic Religion] (Jakarta: Departemen Agama, 1995), h. 12

910 Van der Kroef, Javanese Messianic Expectations', Comparative Studies in Society and History, V(1958-59)

11 Geertz Clifford, Abangan, Santri, Priyayi dalam Masyarakat Jawa, terj. Aswab Mahasin, (Bandung: Dunia Pustaka Jaya, 1981)

12 The word Selamet meaning 'peace' can also be interpreted as a safety (safety) can be juxtaposed with the literal meaning of meaning in harmony (harmoni- 
ous), is the principle of life of rural people in Java.

13 Moh Nazir, Metode Penelitian, Cetakan Ketiga, (Jakarta, Ghalia Indonesia, 1999)

14 Ravik Karsidi, Masyarakat kompleks Perumahan Industri dan Penduduk asli desa sekitarnya. (Yayasan Ilmu-ilmu Sosial: Pustaka Grafiti, 1998), h. 116

15 William F. Ogbur and Meyer F. Nimkoff., Sociology, (Boston, MA: HoughtonMifflin, 1950).

16 Ahmad S. Moussalli, "Modern Islamic Fundamentalist Discources on Civil Society, Pluralism and Democracy" dalam Augustus Richard Norton (Ed.), Civil Society in the Middle East, (1), (Leiden, New York dan Koln: E.J. Brill, 1995), h. 83.

17 Dadang Kahmad, Sosiologi Agama, Bandung: Penerbit PT Remajarosdakarya.,2002 h. 54

18 King, Victor. T. \&Wilder, William. D., The Modern Anthropology of South-East Asia (Routledge Curzon, 2003), h. 1047-1078.

19 Abdurrahman Wahid, Pergulatan Negara, Agama dan Kebudayaan, (Jakarta: Desantar, 2001), h. 24.

20 Clifford Geertz, Abangan, Santri, Priyayi dalam Masyarakat Jawa, terj. Aswab Mahasin, (Bandung: Dunia Pustaka Jaya, 1981)

21 Ibid.

22 Ibid.

23 Nottingham, E. K, Agama dan Masyarakat: Suatu Pengantar Sosiolog, (Jakarta: Rajawali Press, 1993), h. 42,

24 Abdurrahman Wahid, Pergulatan Negara, Agama dan Kebudayaan, (Jakarta: Desantara.2001), h. 111

25 Clifford Geertz, Abangan, Santri, Priyayi dalam Masyarakat Jawa, terj. Aswab Mahasin, (Bandung: Dunia Pustaka Jaya,1981) ph. 10-15

26 Contrary to Geertz's understanding is Mark Woodward's understanding of the religious life of Muslims in Yogyakarta with the distinction between "normative aptitude" and "mysticism." He found that the abangan-santri-priyayi division was not appropriate in the attempt to understand Muslims in Java. Then woodward proposed five basic categories in Islam in Java, namely: local Islam (indigenized Islam), traditionalism, modernism, Islamism, and neomodernism. "Javanese Islam in unique, not because it retains aspects of preMuslim culture and religion but because of the degree to which Sufi concepts of sainthood, the mystical path, and the perfection of man are employed in the formulation of an imperial cult. The state religion is, in turn, a model for traditional Javanese conceptions of social order, ritual and even such aspects of social life as notions of personhood, health and illness" (pg.242).

27 Mark Woodward, Java, Indonesia and Islam in Global Societies Series 3. London, New York: Springer (2011). Dordrecht Heidelberg. DOI 10.1007/978-94-0070056-7, h. 113

28 See Clifford Geertz, The Religion of Java, h. 30-32

29 M. C. Ricklefs follows Geertz as mentioning the tragedy of G 30 S / PKI as 
the articulation of santri and abangan conflicts. Even Ricklefs firmly calls this event a turning point for abangans from Islam to another religion. Lihat M. C. Ricklefs, "Six Centuries of Islamization in Java" dalam Nehemia Levtzion (ed.), Conversion to Islam (New York: Holmes and Meier Publisher, Inc.: 1979), 100-101.

30 Suryo Ediyono, PSHT Logo as Manifestation of Pancasila Ideological Values, Komunitas: International Journal of Indonesian Society and Culture, 8 (2) (2016): h. 309-318. http://dx.doi.org/10.15294/komunitas.v8i2.7322

31 Bambang Sugiharto, Javanese Epistemology,Journal MELINTAS, (24) 3, 369. 384. (2008). Retrieved from http://journal.unpar.ac.id, h. 373

32 Malinowski B, The Dynamics of Culture Change, (New Haven: Yale Univ. Press, 1945), h. 623

33 Ibid, h. 82

34 Harun Hadiwijono, Man in the present Javanese Mysticism, (Netherland: Bosch \& Keuning N.V.,1967). h. 94-115

35 Ricoeur P, The symbolism of Evil Harper in Hobart, M, (1982), 'Is interpretation incompatible with knowledge? the problem of whether the Javanese shadow play has meaning: (University of Bielefeld, 1967) h. 68

36 Harun Hadiwijono, (1967).h. 94-115

37 Prabowo D.P, Pengaruh Islam dalam Karya-karya R.NG. Ronggowarsito, [Trans. Islamic Influence in the works of R.NG Ronggowarsito], Jogjakarta: Narasi (2003)., h. 25

38 See F. Rosenthal, The Classical Heritage in Islam (London: Routledge and KeganPaul, 1975). Juga M. Fakhry, A Short Introduction to Islamic Philosophy, Theology andMysticism (Oxford: Oneword, 1997, h. 135-137.

39 Compare: Darsiti Soeratman, Kehidupan Dunia Keraton Surakarta1830-1939 (Yogyakarta: Yayasan Untuk Indonesia, 2000).

40 c.f.W. H. Groeneveld, Historical Notes on Indonesia and Malaya: Compiled From Chinese Sources (Jakarta: C. V. Bhatara, 1960), h. 49

41 Selamet Mulyana, Runtuhnya Kerajaan Hindu-Jawa dan Timbulnya Negara-Negara Islam di Nusantara (Yogyakarta: LkiS, 2005).

42 A. H. Johns is a major proponent of the theory that Islamization in Indonesia is conducted with a Sufi approach. This is in line with the triumph of Sufism in the Muslim world after the fall of Baghdad into the Mongols in 1258, cited again in M. C. Ricklefs, AHistory of Modern Indonesia since c. 1200, h. 16. Also see Deliar Noer, Gerakan ModernIslam di Indonesia 1900-1942 (Jakarta: LP3ES, 1996), cet. Ke-8, h. 21-22. Alwi Sihab, Islam Inklusif: Menuju Sikap Terbuka dalam Beragama (Bandung: Mizan, 1999), h. 7.

43 Paul Stange reviews the concept of "taste" in the Javanese view. It says "rasa" is not just a term applied to sensory experiences that leads to aesthetics but is also a cognitive organ that is used actively in mystical practicePaul Stange reviews the concept of "taste" in the Javanese view. It says "taste" is not just a term applied to sensory experiences that leads to aesthetics but is also a cognitive organ that is used actively in mystical practice. See Paul Stange, Politik 
Perhatian: Rasa DalamKebudayaan Jawa, terj. Tim LkiS (Yogyakarta: LkiS, 1998), h. 6-7.

\section{BIBLIOGRAPHY}

Bellah, Robert N., and PhillipE. Hammond. 1980. "Varieties of Civil Religion". Journal of church and state. New York: Harper \& Row. ph. 145-146

Benda, Harry J. 1962."Review: The Religion of Java. by Clifford Geertz". The Journal of Asian Studies. Association for Asian Studies. (21), h. 403-406. DOI: $10.2307 / 2050716$

Dalhat, Yusuf. 2015. Islam and the Problem of Social Integration in the West. International Journal of Education and Research. Vol. 3, 7. ISSN: 2411-5681. Diakes pada www.ijern.com

Deutsch, K.W., Sidney A. Burrell, Robert A. Kann, Maurice Lee, Jr., Martin Lichterman, Raymond E. Lindgren, Francis L. Loewenheim, Richard W. Van Wagenen. 1957. "Political Community and the North Atlantic Area". Social Research Vol. 24, No. 4 (Winter 1957), h. 486-488

Ediyono, Suryo. 2016. "PSHT Logo as Manifestation of Pancasila Ideological Values". Komunitas: International Journal of Indonesian Society and Culture, 8 (2) h. 309-318. http://dx.doi.org/10.15294/komunitas.v8i2.7322

Geertz, Clifford. 1981. Abangan, Santri, Priyayi dalam Masyarakat Jawa, terj. Aswab Mahasin, Bandung: Dunia Pustaka Jaya

Johnson, D. Paul. 1988. Teori Sosiologi Klasik dan Modern. Jakarta: Gramedia

Ogburn, William F. and Meyer F. Nimkoff. 1950. Sociology. Boston, MA: Houghton-Mifflin.

Kahmad, Dadang, 2002. Sosiologi Agama, Bandung: Penerbit PT Remajarosdakarya Karsidi, Ravik. 1998. Masyarakat kompleks Perumahan Industri dan Penduduk asli desa sekitarnya. Yayasan Ilmu-ilmu Sosial: Pustaka Grafiti.

King, Victor. T. \& Wilder, William. D., The Modern Anthropology of SouthEast Asia (Routledge Curzon, 2003) dan John R. Bowen "The Form Culture Takes: A State-of-the field essay on the Anthropology of Southeast Asia”, The Journal of Asian Studies, 54: h. 1047-1078.

Rosyada, Dede. 1995. Materi Pokok Agama Islam [Trans. The Subjects of Islamic Religion] Jakarta: Departemen Agama.

Mas'oed, Mohtar. 1991. Politik dan Pemerintahan di Asia Tenggara. PS Ilmu Sosial dan Ilmu Politik. Program Pasca Sarjana UGM. Yogyakarta.

Moussalli, Ahmad S. 1995. "Modern Islamic Fundamentalist Discourses on Civil Society, Pluralism and Democracy" cited in Augustus Richard Norton (Ed.), Civil Society in the Middle East, Volume 1, (Leiden, New York dan Koln: E.J. Brill, 1995), 83; and al-Hasan ibn Talal, "Documentation"

Selamet Mulyana. 2005. Runtuhnya Kerajaan Hindu-Jawa dan Timbulnya NegaraNegara Islam di Nusantara. Yogyakarta: LkiS

Nottingham, E. K. 1993. Agama dan Masyarakat: Suatu Pengantar Sosiologi. Jakarta: Rajawali Press

Robensons, Roland. 1995. Agama dalam Analisa dan Interpretasi Sosiologis, Jakarta: 
PT. RajaGrafindo Persada,

Selamet Mulyana. 2005. Runtuhnya Kerajaan Hindu-Jawa dan Timbulnya NegaraNegara Islam di Nusantara. Yogyakarta: LkiS

Stange, Paul. 1998. Politik Perhatian: Rasa Dalam Kebudayaan Jawa, terj. Tim LkiS Yogyakarta: LkiS, h. 6-7

Sugiharto, Bambang. 2008. "Javanese Epistemology”. Journal MELINTAS, (24) 3, ph. 369-384. Retrieved from http://journal.unpar.ac.id

Van der Kroef. Javanese Messianic Expectations', Comparative Studies in Society and History. V 1958-59

Wahid. Abdurrahman. 2001. Pergulatan Negara, Agama dan Kebudayaan. Jakarta: Desantara

Woodward, Mark. 2011. Java, Indonesia and Islam in Global Societies Series 3. London, New York: Springer Dordrecht Heidelberg. DOI 10.1007/978-94-0070056-7 